\title{
ECONOMIC ASPECTS OF CORPORATE SOCIAL RESPONSIBILITY AND SUSTAINABLE DEVELOPMENT IN COMPANIES
}

\author{
Izabela Wielewska ${ }^{1}$, PhD; Dagmara K. Zuzek ${ }^{2}, \mathrm{PhD}$ \\ ${ }^{1}$ UTP University of Science and Technology in Bydgoszcz, Department of Agrotechnology, Department of \\ Economics and Counseling in Agribusiness, Poland \\ ${ }^{2}$ Agricultural University in Cracow, Faculty of Economics, Department of Economics and Economic Policy
}

\begin{abstract}
The aim of the article was to indicate economic aspects of corporate social responsibility (with special regard to expenditure on environmental protection) in companies based in Pomorskie and Malopolskie Provinces of Poland. The conducted analysis showed that more and more companies conduct their business based on the philosophy of corporate social responsibility, and the expenses borne by the companies on different directions of environmental protection investments are high, while these outlays, except for protecting biodiversity and landscape, are higher in Malopolskie Province. In both Provinces, the companies spend the most of their resources on air and climate protection, while in Malopolskie the enterprises allocate $28.5 \%$ more funds for this purpose than in Pomorskie Province. Also, in terms of expenditures on sewage management, waste management and reduction of noise and vibrations, Malopolskie Province again overtakes Pomerania. Only expenditure on the protection of biodiversity and landscape is higher by $67.6 \%$ in Pomerania as compared to Malopolskie.
\end{abstract}

Key words: corporate social responsibility, environmental protection outlays, sustainable development. JEL code: Q56

\section{Introduction}

Nowadays, the growing role of corporate social responsibility can be noticed, which uses the potential resulting from the use of immaterial enterprise resources, which cannot be bought, or have to be earned for years and years, and these resources become more and more valuable capital (honesty, loyalty, legality of the enterprise). Corporate social responsibility can be included in the modern enterprise management model, which improves and helps to operate in a competitive market and at the same time increases the company's innovativeness.

The need for the development of the aforementioned concept stems not only from the enterprises themselves, but also from the local community, competition, local and central authorities and many other participants of socio-economic life, having an indirect or direct impact on business entities (Zuzek, 2012).

Activities in the field of corporate social responsibility are increasingly taken into account by consumers, for whom not only the price and quality of the product are the most important. What also counts is how the company affects the environment or the local community; the expenditure on environmental protection investments is important, as is regard for the law. Building a strong and stable position on the market is an important element of competitive advantage. Each year, the concept of corporate social responsibility gains more and more supporters and its importance in society increases. It becomes a determinant in business management, which provides significant benefits both in the short and long term, which is extremely valuable from the perspective of the company.

The aim of the article was to indicate economic aspects of corporate social responsibility (with special regard to expenditure on environmental protection) in companies based in Pomorskie and Malopolskie Provinces of Poland. The conducted analysis showed that more and more companies conduct their business based on the philosophy of corporate social responsibility, and the expenses borne by the companies on different directions of environmental protection investments are high, 
while these outlays, exceptfor protecting biodiversity and landscape, are higher in Malopolskie Province.

\section{Research results and discussion}

\section{The concept and areas covered by corporate social responsibility activities}

The concept of corporate social responsibility (CSR) has found wide recognition in recent years among both practitioners and theoreticians of economic sciences. Increasingly, this term is used by economists, lawyers, political scientists, psychologists, sociologists and business ethicists. An important feature of this concept is its interdisciplinary nature which shows the need for integration and knowledge in various fields of science and business practice.

The idea of CSR goes back to the concept of sustainable development, established at the turn of the 1960s and 1970s in the United States and Western Europe, according to which not only the economic, but also the social and environmental aspect is important in economic development. This allows to keep a balance between these elements in the company's activities, and thus can contribute to the goals that are attributed to sustainable development, in particular the conservation of natural resources and maintaining ecosystems' stability, with all its positive effects such as improving human health and an improvement in general security and well-being" (Bogdanienko, 2011).

In the subject literature, many areas of corporate social responsibility activities can be found that are related to the market, the natural environment or the local community in which the enterprise operates. Responsible actions in this area should include the process of obtaining a product or service, starting from supplies, through manufacturing technology to marketing activities. Sustainable development in this area also depends on keeping deadlines for payments and deliveries, or monitoring the quality of products or services provided, which should meet the quality and safety standards required for them. An important aspect is also the company's support of the local economy by creating business cooperation with local business people (Chojnacka, 2013).

One of the key areas for companies is also the natural environment, due to the fact that its interests are usually represented by non-governmental environmental organizations. Along with the growing prospects of ecological threats and the fact that the environment is no longer becoming a factor but a barrier to development, the importance of its protection and sustainable development increases. The basic task of companies in taking care of the environment is to minimize the negative impact on them by reducing resource consumption, reducing pollutant emissions, recycling, and developing environmentally friendly technologies. Responsibility for the local community may refer to such issues as: support for local initiatives, cooperation with local authorities or social organizations. Business companies influence the development and integration of local communities by creating jobs, by providing adequate benefits and remuneration, and by paying taxes, which are the main source of revenue for the budgets of local governments. Positive perception of the company and its activities helps in efficient functioning in the local community and translates into gaining its support and acceptance of the actions undertaken (Chojnacka, 2013).

The subject literature also mentions two dimensions of corporate social responsibility, which consist of ten areas. In the internal dimension referring to the conditions of the company's functioning, there are six issues: human resources management, ethical programs for employees, 
occupational health and safety, ability to adapt to changes, environmental protection management and corporate governance principles. In the external dimension, focusing on the importance of the company to external stakeholders, the following areas were distinguished: local community, trade partners, suppliers, customers, human rights and global environmental problems (Rok, 2004).

The basic activity in the process of implementing the CSR strategy is to determine the actions that should be implemented and to specify the knowledge in this area. It is important that the company's environment should recognize the need to take socially responsible actions and be convinced that it is a beneficial process for both them and the company itself. The basis for these activities should be detailed conveyance of information on the CRS, planned activities related to its implementation and conducting a dialogue with stakeholders in order to understand their needs, expectations and opinions. At this stage, it is also necessary to define the areas in which the company will be developing (Paliwoda-Matiolanska, 2011).

The next step is to set goals, procedures and activities that are extremely important from the point of view of effective implementation of corporate social responsibility. A detailed scope of activities supports the effective implementation of the developed policy, aimed at the use of opportunities and avoidance. The last link in the implementation phase is communicating the results of analyses and CSR goals. The next stage is the implementation of a system, which is based on effective implementation and realisation of tasks resulting from the developed procedures. This is the stage in which it is critical to constantly monitor the results and practices undertaken, in order to quickly rectify and prevent errors (Filek, 2002).

The last stage of the CSR implementation process is management (PDCA). It consists of monitoring the realisation of objectives and development and an assessment of the level of effectiveness of the implemented system and adopted policy. It is also important to efficiently reach the largest group of recipients possible. Presenting the projects completed by the company in a company newsletter or on an intranet site or on a bulletin board not only creates the company image, but also helps to motivate employees and encourages new clients to cooperate. An integral part of communication of corporate social responsibility is making reports. Not only are such studies an important element of building the image, but they also allow a wider audience to become acquainted with the achievements completed so far (Juzefczyk, 2013).

The list of benefits which arise from implementing CRS in the company's operation is incomparably longer than the one of unfavourable aspects of this strategy. This gives companies an impulse to act and make a considerable effort related to implementation and drives them to set ambitious goals, for example in the field of environmental protection, building relationships with the local community or creating better jobs. In today's economy, companies need to use various forms and methods of influencing the environment in order to gain the trust of clients, investors and employees. A well-implemented CSR will probably be a source of competitive advantage. Naturally, it will not happen overnight. CSR is a long-term strategy that requires time and patience, but in the long term it brings many benefits. For the company, this results in shaping a good image among employees who are more aware of the company's functioning, when they see that its activities affect solving significant social problems. It is also a good way of non-financial motivation for the employees who identify with the tasks performed by the company, which means that they work more efficiently and effectively. There is also a growth of interest among stakeholders who are more willing to cooperate with enterprises that, apart from good financial results, are also managed in a transparent manner and build their image responsibly. Building relationships with the 
local community and authorities through active participation in social life and making decisions about investments will enable the development of local infrastructure and the community itself, which in turn will help to win its favour as well as gain trust and develop good relations with the local government. The benefits presented above are an example of the fact that the CSR strategy is not a cost but an investment for an enterprise that, in the long run, brings profit to the company (Zaplata, Kazmierczak, 2011).

\section{Expenditure on environmental protection in Pomorskie and Malopolskie Provinces}

As mentioned before, environmental protection is one of the key areas of business activity. Since economic activity often interferes with the needs of the natural environment, management in contemporary enterprises must address certain aspects of sustainable development related to environmental protection. This activity involves various methods of protection. In this respect, the most important is the pursuit of appropriate pro-ecological investments. According to I. Wielewska (2015), the necessary condition for an investment to be recognised as ecological is its management towards environmental protection.

In this study, special attention was paid to the activities and responsibility of enterprises for the condition of the environment and a comparative analysis was done of outlays on environmental protection in two Provinces, namely Pomorskie and Malopolskie, located on the opposite ends of Poland. Pomorskie is located in the northern part of Poland, and Malopolskie is located in the southern part. The area of Pomorskie is 18.3 thousand sq. km, and of Malopolskie - 15.2 thousand sq. $\mathrm{km}$. The number of people per sq. $\mathrm{km}$ is higher in Malopolskie (223 people/sq. $\mathrm{km}$ ) than in Pomorskie (126 people/sq. km) (Area and Population in Territorial Cross-section in 2017, p. 17) .

Table 1

\section{Selected environmental threats in Poland, in Pomorskie and Malopolskie Provinces in 2016}

\begin{tabular}{|l|l|c|c|c|}
\hline No. & \multicolumn{1}{|c|}{ Threats } & Poland & \multicolumn{1}{|c|}{$\begin{array}{c}\text { Pomorskie } \\
\text { Province }\end{array}$} & $\begin{array}{c}\text { Malopolskie } \\
\text { Province }\end{array}$ \\
\hline 1. & $\begin{array}{l}\text { Industrial and municipal wastewater requiring } \\
\text { treatment (in hm } \text { h }^{\text {P }}\end{array}$ & 2166.0 & 130.8 & 259.3 \\
\hline 2. & $\begin{array}{l}\text { Emission of dust air pollutants from particularly } \\
\text { burdensome plants (thousands of tons) }\end{array}$ & 38.6 & 1.9 & 2.1 \\
\hline 3. & $\begin{array}{l}\text { Emission of gaseous air pollutants from particularly } \\
\text { burdensome plants (thousands of tons) }\end{array}$ & 210849.4 & 6826,5 & 10059.5 \\
\hline 4. & Waste, excluding municipal (thousands of tons) & 128306.9 & 2092.4 & 4810.9 \\
\hline
\end{tabular}

The data contained in Table 1 show that the scale of environmental pollution in both regions differs significantly. The region of Malopolskie Province is more polluted than Pomorskie in all the criteria presented. The state of pollution translates into expenditures that both regions allocate to various types of investment directions which support environmental protection.

It should be noted that the total expenditure on environmental protection is the sum of outlays on fixed assets used to protect the environment and running costs. In turn, capital expenditures are financial or material outlays whose aim is to create new fixed assets or to improve (reconstruction, extension, adaptation or modernization) the existing fixed assets as well as expenditures on the so-called first investment equipment (Environmental Protection, 2017, p. 366). 


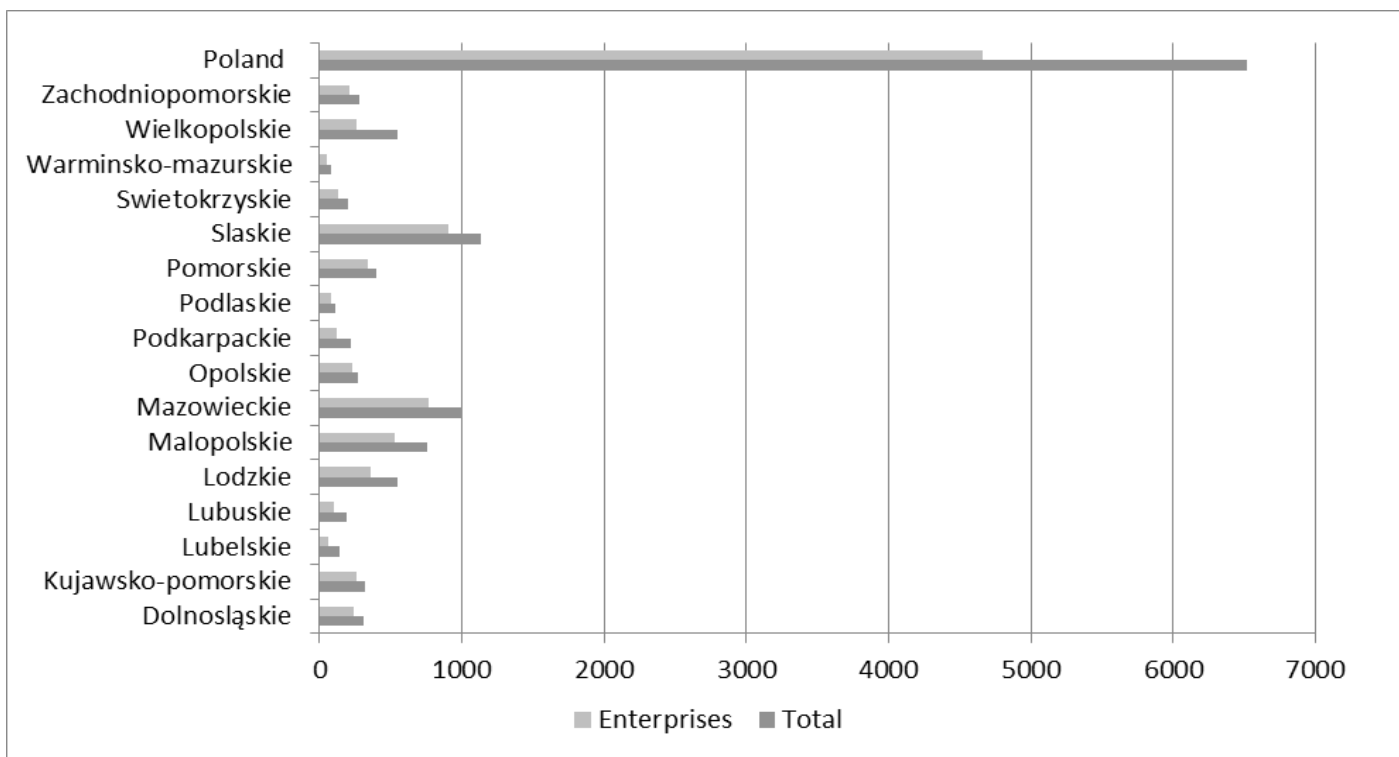

Source: based on Environmental Protection, Central Statistical Office, Warsaw 2017, p. 391

Fig. 1. Capital expenditure on fixed assets used to protect the environment in 2016 in millions PLN.

The data presented in Figure 1 shows that in Poland, the expenditure on fixed assets for environmental protection amounted to a total of PLN 6517.0 million, of which expenditures borne by the enterprises themselves amounted to PLN 4658.1 million. The highest expenditures were incurred by enterprises in Slaskie Province (PLN 906.4 million), and the lowest in WarminskoMazurskie Province (PLN 51.3 million).

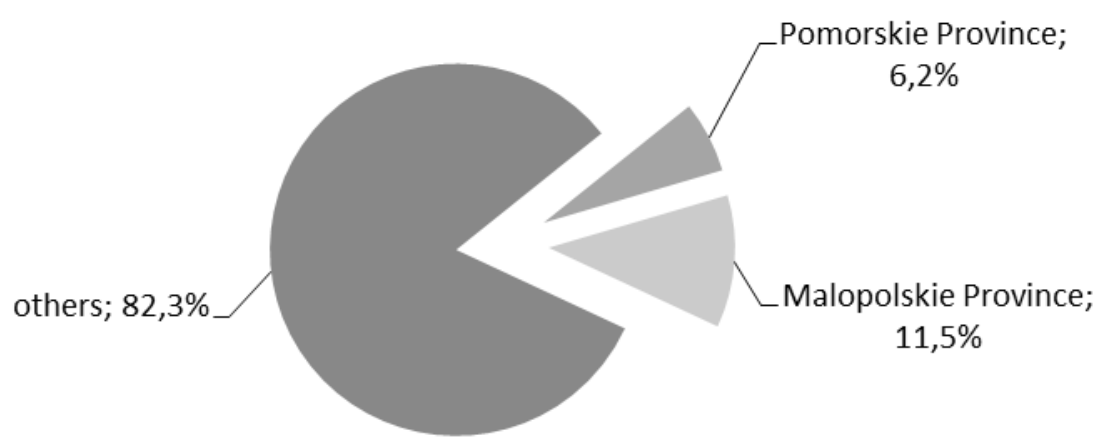

Source: author's own study.

\section{Fig. 2. Capital expenditure on environmental protection in enterprises located in Pomorskie} and Malopolskie Provinces in 2016 [ \%]

In Pomorskie Province, expenditures on fixed assets amounted to PLN 402.3 million (6.2 \%) and were by $5.3 \%$ lower than those of Malopolskie $(11.5 \%)$. The most expenditures in Pomorskie Province allocated to the fixed assets of environmental protection were incurred by the Tri-City (Gdansk, Sopot, Gdynia) sub-region (58.2\%) and the least in Slupsk area. In Malopolskie Province, the largest expenditure was borne by Krakow urban sub-region, and the smallest by Nowy Targ urban sub-region (Table 2 ). 
Capital expenditures on fixed assets for environmental protection in enterprises located in Pomorskie and Malopolskie Provinces, by sub-regions in 2016, in millions PLN

\begin{tabular}{|c|c|c|c|}
\hline No. & Specification & $\begin{array}{c}\text { Capital } \\
\text { expenditures on } \\
\text { fixed assets for } \\
\text { environmental } \\
\text { protection }\end{array}$ & $\%$ \\
\hline 1. & Pomorskie Province & $402 ., 3$ & 100 \\
\hline 2. & \multicolumn{3}{|l|}{ Subregions: } \\
\hline 3. & Chojnicki & 33.7 & 8.4 \\
\hline 4. & Gdanski & 47.4 & 11.8 \\
\hline 5. & Slupski & 23.6 & 5.9 \\
\hline 6. & Starogardzki & 63.3 & 15.7 \\
\hline 7. & Trojmiejski & 234.3 & 58.2 \\
\hline 8. & Malopolskie Province & 752.7 & 100 \\
\hline 9. & \multicolumn{3}{|l|}{ Subregions: } \\
\hline 10. & Krakowski & 66.1 & 8.9 \\
\hline 11. & m. Krakow & 362.3 & 48.1 \\
\hline 12. & Nowosadecki & 32.4 & 4.3 \\
\hline 13. & Nowotarski & 31.0 & 4.4 \\
\hline 14. & Oswiecimski & 171.7 & 22.8 \\
\hline 15. & Tarnowski & 89.1 & 11.8 \\
\hline
\end{tabular}

Source: based on Environmental Protection, Central Statistical Office, Warsaw 2017, pp. 70-71.

\section{Capital expenditures of enterprises on environmental protection, by directions of investment countrywide in 2016 (current prices)}

\begin{tabular}{|l|l|c|c|}
\hline No. & \multicolumn{1}{|c|}{ Directions of investment countrywide } & $\begin{array}{c}\text { Total } \\
\text { in thous. } \\
\text { PLN }\end{array}$ & $\begin{array}{c}\text { Enterprises } \\
\text { in thous. } \\
\text { PLN }\end{array}$ \\
\hline 1. & Air protection & 2520672.7 & 2355706.7 \\
\hline 2. & Wastewater management and protection of water & 2277332.9 & 1257731.9 \\
\hline 3. & Waste management & 904242.5 & 750850.1 \\
\hline 4. & $\begin{array}{l}\text { Protection and restoration of utility value of soil, protection of } \\
\text { groundwater and surface water }\end{array}$ & 60134.5 & 45747.7 \\
\hline 5. & Noise and vibration reduction & 186828.2 & 45303.8 \\
\hline 6. & Protection of biodiversity and landscape & 109144.7 & 3881.3 \\
\hline 7. & Protection against ionizing radiation & 913.5 & 589.4 \\
\hline 8. & Research and development activity & 4625.0 & 4625.0 \\
\hline 9. & Other environmental protection activities & 453141.4 & 193697.9 \\
\hline
\end{tabular}

Source: based on Environmental Protection, Central Statistical Office, Warsaw 2017, pp. 391-395.

The analysis shows that the enterprises from both Provinces consider their primary CSR activities to be conducting their business in the perspective of the impact on the natural environment and the company's environment, which is consistent with the principles of ecology. The most significant aspect in environmental protection from the point of view of expenditures is particularly air protection as well as sewage management and water protection. These two 
directions of investment account for as much as $77.6 \%$ of all outlays on fixed assets for environmental protection in the country.

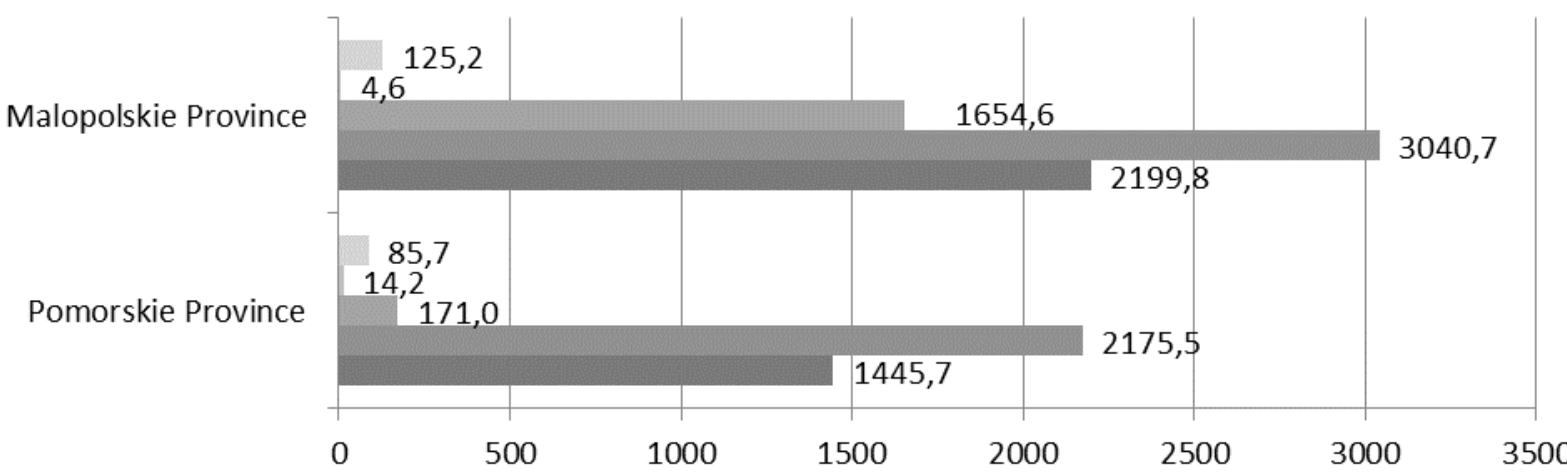

$$
\begin{aligned}
& \text { noise and vibration reduction } \\
& \text { protection of biodiversity and landscape } \\
& \text { waste management } \\
& \text { protection of air and climate } \\
& \text { wastewater management and protection of water }
\end{aligned}
$$

Source: based on Environmental Protection, Central Statistical Office, Warsaw 2017, p. 396.

Fig. 3. Capital expenditures of enterprises on fixed assets for environmental protection, by investment directions in Pomorskie and Malopolskie Provinces in 2016 (PLN million)

Both in Pomorskie and Malopolskie Provinces, the companies spend the most resources on air and climate protection, while in Malopolskie, the enterprises spend $28.5 \%$ more than in Pomorskie. Also, in terms of expenditures on sewage management, waste management and reduction of noise and vibrations, Malopolskie Province overtakes Pomorskie. Only expenditure on the protection of biodiversity and landscape is higher in Pomorskie Province by $67.6 \%$ compared to Malopolskie Province.

\section{Conclusions}

1) The economic aspects of corporate social responsibility are becoming an increasingly important element of Polish enterprises. The number of companies that operate according to the CSR philosophy is increasing. The focus of the company's activity is now on the activity accordant with the principles of eco-development, based on balancing profits and losses in three areas: economy, environment and society.

2) The analysis shows that in Poland, the expenditure on fixed assets for environmental protection amounted to a total of PLN 6517.0 million, of which the enterprises allocated PLN 4658.1 million for this purpose. In Malopolskie Province, 5.3 \% more funds were spent on various directions of environmental protection than in Pomorskie Province. Only Pomorskie's enterprises spent $67.6 \%$ more on protecting biological diversity than companies from Malopolskie.

3) It can be concluded that CSR awareness of contemporary Polish businesspeople is increasing, which translates into an increase in pro-ecological investments.

\section{Acknowledgement}

Publication financed by BS 53/2014 "Contemporary changes in the functioning of the country and agriculture in the light of the Common Agricultural Policy of the EU"from subsidies for maintenance : 
- of research potential granted by Ministry of Science and Author

- Higher Education Author

\section{Bibliography}

1. Bogdanienko J. (2011). Odpowiedzialnosc spoleczna a strategia organizacji (Social Responsibility and the Strategy of an Organisation). (in:) Biernatt M., Bogdanienka J., Skoczny T. (ed.), Spoleczna odpowiedzialnosc biznesu. Krytyczna analiza (Corporate Social Responsibility. A Critical Analysis). Warszawa: Wydawnictwo Naukowe Wydzialu Zarzadzania Uniwersytetu Warszawskiego.

2. Chojnacka M. (2013). Zagrozenia spolecznej odpowiedzialnosci w architekturze wspolczesnego otoczenia (Threats of Social Responsibility in the Architecture of Contemporary Environment). (in:) Społeczna odpowiedzialnosc biznesu (Corporate Social Responsibility), ed. by Rossa J., Chojnacka M., Gorzow Wielkopolski: Wydawnictwo Panstwowej Wyzszej Szkoly Zawodowej im. Jakuba z Paradyza.

3. Filek J. (2002). O wolnosci i odpowiedzialnosci podmiotu gospodarczego (Of Freedom and Responsibility of a Business Entity). Krakow: Wydawnictwo Akademii Ekonomicznej.

4. Juzefczyk A. (ed.), (2013). Wdrazanie narzedzi spolecznej odpowiedzialnosci biznesu przez organizacje pozarzadowe, Gdynia: Fundusz Inicjatyw Obywatelskich.

5. Ochrona srodowiska (2017). (Environmental Protection). Warszawa: GUS.

6. Paliwoda-Matiolanska A. (2014). Odpowiedzialnosc spoleczna w procesie zarzadzania przedsiebiorstwem (Social Responsibility in the Process of Company Management). Wydawnictwo C.H.BECK, Warszawa

7. Powierzchnia i ludnosc w przekroju terytorialnym w 2017 roku (2017). (Area and Population in Territorial Cross-section in 2017). Warszawa: GUS.

8. Rok B. (2004). Odpowiedzialny biznes w nieodpowiedzialnym swiecie (Responsible Business in an Irresponsible World). Warszawa: Akademia Rozwoju Filantropii w Polsce. Forum Odpowiedzialnego Biznesu.

9. Wielewska, I. (2015). Ecological investments as a necessary condition for sustainable development of agribusiness companies. In: Economic Science for Rural Development. Rural Development and Entrepreneurship. Proceedings of the International Scientific Conference. Jelgava: Latvia University of Agriculture, No 39, 47-56.

10. Zaplata S., Kazmierczak M. (2011). Ryzyko, ciaglosc biznesu, odpowiedzialnosc społeczna. Nowoczesne koncepcje zarzadzania (Risk, Business Continuity, Social Responsibility. Modern Management Concepts), Warszawa: Wydawnictwo Oficyna Wolters Kluwer Business.

11. Zuzek D. (2012). Spoleczna odpowiedzialnosc biznesu a zrownowazony rozwoj przedsiebiorstw (Corporate Social Responsibility and Sustainable Development of Companies). Tarnow: Zeszyty Naukowe Malopolskiej Wyzszej Szkoly Ekonomicznej w Tarnowie, vol. 21, No. 2. 